\title{
Knowledge and perception of small holding farmers on supplementation and feeding sweet potato vines to goats
}

\author{
Cynthia Fikile Luthuli ${ }^{1,2}$, Fabian Nde Fon ${ }^{1}$ and Busisiwe Gunya ${ }^{1,3^{*}}$ [D
}

\begin{abstract}
Goats in rural communities are often raised in conditions which do not allow them to achieve their maximum performance nor express their genetic potentials. For goats to perform to their full potential, they require high nutritious feed especially in the winter season when there is food shortage or during high milk-producing periods. However, supplementation can be done using fresh green feeds, protein blocks or vitamins which are often expensive, hence the need to source for indigenous crop residues. This study assessed the knowledge and perceptions of farmers on feeding sweet potato vines to their goats. The data were gathered by administering a total of 105 structured questionnaires using face-to-face interviews. The results showed that the majority of farmers (71.4\%) were aware and practise some sort of supplementary feeding. Most farmers (72.4\%) cultivated sweet potatoes, and they used them for different purposes such as income generation (53.3\%), consumption (27.5\%) or both (8\%). Sweet potato vines were being discarded as waste or burnt (32.4\%), left on the field as manure (25.7\%), conserved as propagation material (8.6\%) or randomly fed to livestock (7.6\%). Nevertheless, most of the farmers (78.1\%) rejected the use of sweet potato vines as feed to livestock. In conclusion, more intervention measures are required for developing farmers' knowledge and perception on feeding sweet potatoe vines to livestock. Farmers may be assisted through training and workshops on the use of sweet potato vines and other indigenous forage supplementation as feed.
\end{abstract}

Keywords: Sweet potato vines, Traditional knowledge, Feed, Supplementation

\section{Introduction}

Hodges et al. (2014) explain that livestock is a major role player in supplying protein to people in the form of meat, milk and skin. Livestock also contributes enormously to employment globally which is not different in South Africa where the livestock sector employs more than 245,000 workers (Meissner et al. 2013). Goats are one of the important farm animals and are known for being easy and cheaper to manage. Hence, most of the goats' products (such as hides, meat and milk) are valuable and may be efficiently used for income generation. In sub-Saharan Africa the southern region has the majority of goats. Different breeds of goats include Nguni,

\footnotetext{
* Correspondence: GunyaB@unizulu.ac.za

${ }^{1}$ Department of Agriculture, Faculty of Science and Agriculture, University of Zululand, Private Bag X 1001, Kwa-Dlangezwa 3886, South Africa

${ }^{3}$ Department of Agricultural Economics and Animal Production, Faculty of Science and Agriculture, University of Limpopo, Private Bag X1106, Sovenga 0727, South Africa

Full list of author information is available at the end of the article
}

Matebele, Mashona, Tswana and Landim (Gwaze et al. 2010). These breeds are also regarded as indigenous, with the Nguni breed mostly found in the KwaZuluNatal and Eastern Cape Provinces of South Africa.

The main challenges for goat production in these rural areas are shortages of feed, diseases especially helminthic, poor management and lack of marketing strategies (Gwaze et al. 2010). Lack of knowledge on subsistence farming system is also regarded as a challenge, and farmers' traditional beliefs (e.g. witchcraft) around their production system also need attention since it affects livestock management practices (Hesterberg et al. 2007). Addressing the issue of limited forage for goats may have a positive impact in resolving the abovementioned constraints. There are traditional food crop residues such as cassava, banana, nuts and sweet potato that could be used to supplement goat feed.

Sweet potatoes are utilised as food crop almost in the whole tropical world due to its nutrient status, but the 
residues are not properly exploited (Motsa et al. 2015). However, sweet potato residues are being utilised as feed in some countries of Africa (Hadgu et al. 2014). Apart from being feed, sweet potatoes are recorded to have medicinal properties (Meira et al. 2012). Moreover, there is very little or no information about farmers feeding sweet potato to ruminants in South Africa and specifically in KwaZuluNatal. This information needs to be investigated to find out whether there are any farmers feeding sweet potato vines to ruminants. Furthermore, farmers in a subsistence environment are less involved in the cultivation of pastures for livestock feeding (Maassa et al. 2013). Thus, there is a need to study and validate their information that might be of help in the farming environment at large; therefore, the objective of this study was to determine the knowledge and perception of smallholding farmers, concerning supplementation and feeding sweet potato vines to goats.

\section{Study area}

Data for the survey was collected in the KwaMthethwa area (seven wards), a community of Umhlathuze Municipality, KwaZulu-Natal Province of South Africa, which is found within $28^{\circ} 31^{\prime} \mathrm{S}$ latitude and $31^{\circ} 51^{\prime} \mathrm{E}$ longitude. KwaMthethwa receives rainfall of about $900 \mathrm{~mm}$ per annum and $26^{\circ} \mathrm{C}$ mean temperature per annum (Kunene et al. 2015).

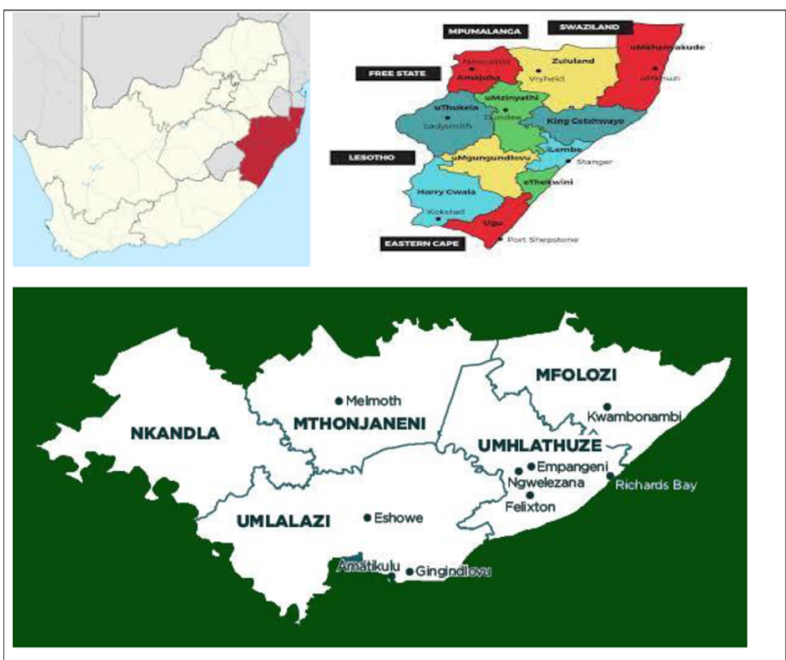

\section{Materials and methods}

\section{Farmer selection procedures}

The focus of this study was more on community farmers who owned livestock. A total of 105 farmers, 15 homesteads from each of the seven wards, were interviewed with the aim of evaluating the knowledge of farmers on supplementary feeding and their perceptions towards feeding sweet potato vines to goats. The farmers were chosen with the help of extension officers who informed them about the visit. In a subsequent meeting, farmers were presented with an informed consent form translated in isiZulu where the farmer cannot read English and the interview was conducted in IsiZulu which is their vernacular language.

\section{Data collection}

Data was collected using a structured questionnaire that involved four sections labelled as A, B, C, and D. Section $\mathrm{A}$ included the biodata and some background information of the farmer. Section B included livestock inventory to find out the type and quantity of livestock the farmer owns. Section C consisted of questions in connection with supplementary feeding as well as the farmers' perception towards sweet potato vines as animal feed. Questionnaires were written in isiZulu. Farmers were assessed at their selection and allowed to withdraw anytime during the survey if they wish so. Data collection was done by the researcher to ensure the correctness of data, assisted by an extension officer and a colleague from OSCA Research Station.

\section{Data analysis}

Data collected from the study were analysed using SPSS (2015). The frequency procedure was used to generate frequencies pertaining to household demographics. A chi-square test was used to test whether there is any association between observed variables and smallholder farmers' knowledge and perception on supplementation and feeding of sweet potato vines to goats.

\section{Results}

Demographic information of participants

Demographic information of participants is presented in Table 1. The results showed that the number of males practising agriculture was significantly higher $(56.2 \%)$ as compared to that of females (43.8\%). The number of participants varied according to age groups: age group 56-65 had the highest participants, whilst 18-28, 26-35 and 3645 had the least. The literacy level was also high as most of the participants had completed the secondary level.

\section{Livestock inventory}

The livestock inventory is shown in Table 2. Out of 105 farmers interviewed, $40 \%$ owned between 1 and 10 cattle. The majority $(92.4 \%)$ of farmers had no sheep whilst goats were being the most farmed animal though they were in small numbers per household.

\section{Purpose of goat farming}

The reasons for keeping goats varied from prestige to income, then consumption, as shown in Fig. 1. The majority of farmers (71.4\%) kept goats for tradition or prestige 
Table 1 Demographic characteristics of participants

\begin{tabular}{lll}
\hline & No. of farmers & Percent \\
\hline Gender & 59 & 56.2 \\
Male & 46 & 43.8 \\
Female & 105 & 100.0 \\
Total & & \\
Age of respondents & 16 & 15.2 \\
18-25 & 16 & 15.2 \\
26-35 & 16 & 15.2 \\
36-45 & 18 & 17.1 \\
46-55 & 22 & 21.1 \\
56-65 & 17 & 16.2 \\
65+ & 105 & 100.0 \\
Total & & \\
Level of education & 26 & 24.8 \\
Never & 31 & 29.5 \\
Primary level & 48 & 45.7 \\
High school & 105 & 100.0 \\
Total & & \\
Occupation & 99 & 94.3 \\
Farmer & 6.7 \\
Others & & 100.0 \\
Total & & \\
\hline
\end{tabular}

followed by those (15.3\%) who were making income from goat production, whilst the least number of farmers (13.3\%) kept goats for consumption.

\section{Supplement source for goats}

The results showed that most farmers (71.4\%) were aware and do practise some sort of supplementary feeding, whereas only $28.6 \%$ of farmers were not supplementing.

The participants were supplementing with different feed sources. Supplementary feeds used by farmers were either bought or from crop residues or from indigenous

Table 2 Livestock inventory (cattle, sheep and goats) in percentage

\begin{tabular}{llll}
\hline Livestock numbers & Cattle & Sheep & Goats \\
\hline 0 & 54.4 & 92.4 & 6.6 \\
$1-10$ & 40 & 4.75 & 51.5 \\
$11-20$ & 4.75 & 1.9 & 26.7 \\
$21-30$ & 0.85 & - & 9.5 \\
$31-40$ & - & 0.95 & 1.9 \\
$41-50$ & - & - & 1.9 \\
$51+$ & - & - & 1.9 \\
Total & 100 & 100 & 100 \\
\hline
\end{tabular}

trees (Fig. 2). The biggest group of farmers (34.3\%) bought supplementary feed for their animals.

\section{Farmers' perception on the use of sweet potatoes as supplement feed for goats}

A significant number of farmers were cultivating sweet potatoes, whereas few of them did not, $72.4 \%$ and $27.6 \%$ respectively.

The majority of farmers $(51.3 \%)$ were cultivating sweet potatoes for consumption, and the least farmers (7\%) cultivated for both income and consumption. The reasons for cultivating sweet potatoes varied amongst farmers. The most favoured reason for cultivating sweet potatoes was for consumption followed by generation of income, and the least reason was a combination of income generation and consumption.

\section{Discussion}

\section{Biodata of farmers}

Domination of males in the livestock production sector is still high compared to the number of females that were observed. Male dominion seemed to be above the national statistical average of $52.1 \%$ males and $41.18 \%$ females heading agricultural households that were reported by Statistics South Africa (2013). However, in this survey, a little improvement had been demonstrated in the male-to-female ratio when compared with the results reported by Mahanjana et al. (2004) who reported that the male-to-female ratio (68\% male) was similar to KwaZulu-Natal. Moreover, interventions are still required to ensure the greater involvement of women in agriculture.

The level of education also varied across the ages of respondents. Respondents below the age of 45 years were educated compared to those above this age. This as well is a good indication since agriculture demands people in farming business to have basic education, for them to be able to utilise relevant information available at their disposal. In addition, supplementary feeding needs someone who can understand the nutritional requirements of the animals, to be able to measure the required feed proportions correctly. Hence, the educational level may have had an influence on farmers' application of indigenous crop residues (Maassa et al. 2012). However, farmers that were participating in livestock production were above the ages of 41. According to the findings by Thornton (2008), the youth stated that they were not interested in agriculture. This may be attributed to lack of knowledge, passion or role modelling that may encourage or motivate the youth to engage in agricultural activities. Some of the youth also prefer to go searching for jobs in urban areas to get immediate salaries rather than to take the risk of farming. In addition, older people uphold the indigenous knowledge and methods of ensuring 


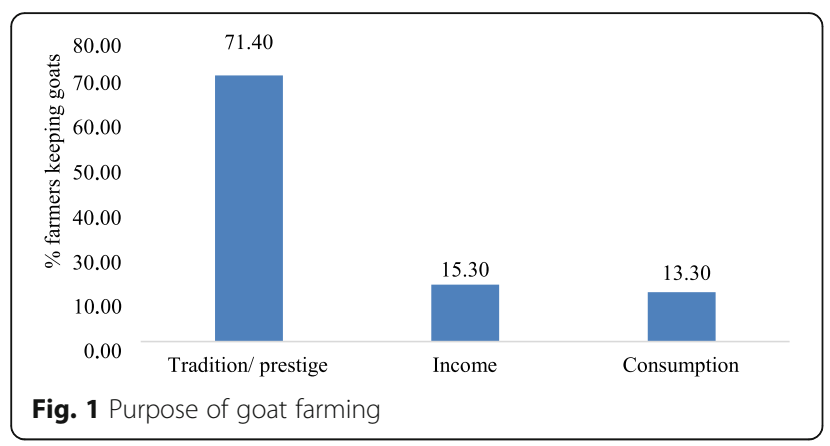

sustainability of their minimum agricultural resources whilst trying hard to transfer it to the modernised youth of today (Agyepong 2009).

\section{Livestock ownership and population}

In this study, there was a variation in flock size of farmers, which may be due to their farming practices, diseases, theft, lack of knowledge of breeding and other socioeconomic factors. Most farmers had livestock which is in line with findings of Reddy et al. (2016) who reported that in Limpopo and Mpumalanga Provinces almost all households own livestock, which ensure that smallholding farmers have somehow secured food. In this study, goats were the main species owned by farmers, followed by cattle then sheep; this contradicts findings by Munyai (2012), who reported cattle were more dominant in rural communities. This may be attributed to the fact that goats are used in many cultural activities such as lobola (bride price), and traditional ceremonies (Braker et al. 2002).

\section{Reasons for keeping livestock}

According to Rao (2013) and Meissner et al. (2013), livestock serves as capital investment and a major source of protein in tropical and semi-arid areas, especially in Africa where the majority of livstock is found in resource-poor communities. This was not expected to be different in this study. Goats are also used as a surety by rural communities, especially during times of need (Meissner et al. 2013). However, this study showed that most farmers in the KwaMthethwa community area kept their goats for socio-economic (traditional and prestige) reasons and income generation. These results concur with the findings of Munyai (2012) who reported that $76 \%$ of farmers keep livestock for prestige and $16 \%$ for income generation purposes. Socio-economic status seems to be a barrier in the production system and development of small-scale farmers, since livestock is less utilised for generation of income. Livestock production with an aim of income generation may assist in the purchases of forage especially in the winter or during the drought season. However, this is mostly realised during drought where farmers lose most of their livestock due to forage shortages, disease and high rates of abortions as a result of malnutrition. According to Munyai (2012), farmers end up practising pastoralism, whereby farmers themselves had to herd or hire a herder to move from one area to another in search of forages for livestock. Therefore, farmers need to be encouraged to sell or cull their male animals to ensure good investments in the smallholding farming business (Tsheole et al. 2016). Income received may be used towards building and taking care of their breeding (producing) stock to ensure they can earn good profits and grow to commercial farming, thus increase a country's economy as well.

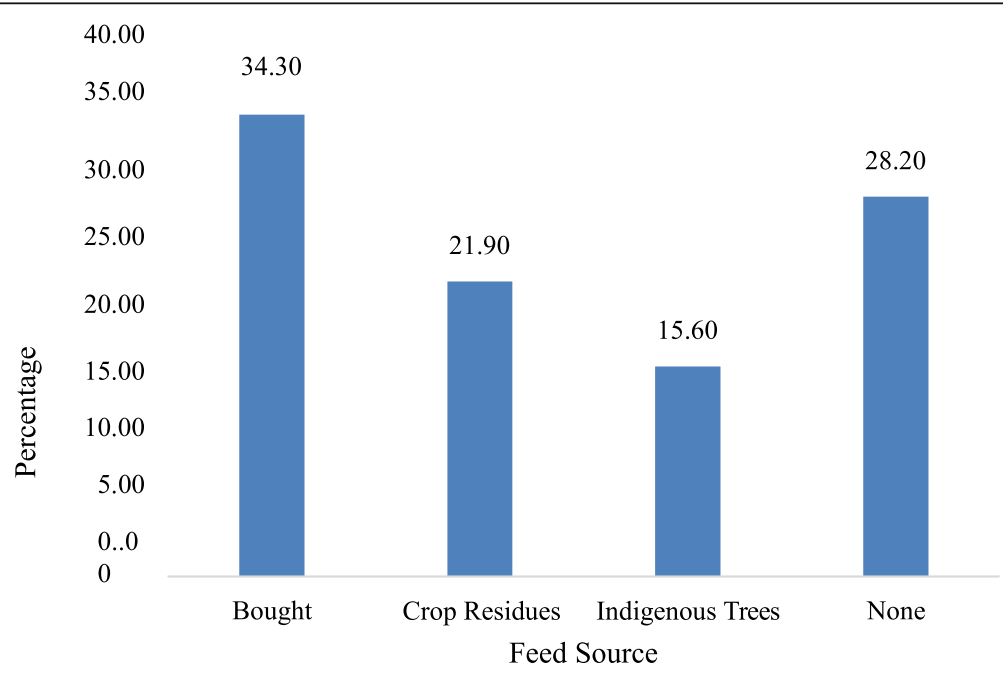

Fig. 2 Material used as a source of feed for supplementary purposes 


\section{Farmers practising supplementary feeding}

Most farmers knew about supplementation and were supplementing with purchased maize for goats every afternoon when goats come back for kraaling in the afternoons without a herder. However, a certain number of people were not practising supplementation at all. These results contradict findings by Munyai (2012) who reported that most small-scale farmers use crop residues for supplementary feeding. This was attributed to the fact that the KwaZulu-Natal was going through a severe drought and most farmers were not cultivating any food crops; hence, most farmers were buying maize which may be very expensive if bought specifically for supplementing other than kraaling.

\section{Sweet potato uses}

In this study, most farmers cultivated sweet potatoes for consumption followed by income generation whereas the least farmers cultivated sweet potatoes for both consumption and income generation (Table 3). This is consistent with the results found by Naidoo et al. (2016), who reported that sweet potato is grown as staple food mostly by poor communities in South Africa, especially in KwaZulu-Natal, Limpopo, Western Cape and Mpumalanga Provinces. Moreover, this shows that most farmers work towards generating their own food security. The statistics by DAFF (2011) showed that there is a huge production of sweet potatoes in South Africa which surpasses consumption; as a result, surplus is being exported to other countries such as the UK, Netherlands and France. This is an indication that there is a potential for growth for small-scale farmers if proper interventions are being employed and policies being developed to increase sweet potato production in SA.

\section{Uses of sweet potato vines and perceptions of farmers towards using vines as feed}

The current study is in accordance with the results by Munyai (2012), who reported that farmers use some of crop residues such as sweet potatoes from their fields as animal feed. Hence, sweet potato is one of the crops being produced by emerging farmers in South Africa.

Table 3 Uses of sweet potato vines

\begin{tabular}{lll}
\hline Uses of sweet potato vines & No. of farmers & Percent \\
\hline None & 27 & 25.7 \\
Feed to livestock & 8 & 7.6 \\
Leave as mulch or manure & 27 & 25.7 \\
Throw away or burnt & 34 & 32.4 \\
Preserve as propagation material & 9 & 8.6 \\
Total & 105 & 100.0 \\
\hline
\end{tabular}

Sweet potatoes are mostly used as a staple food in most developing countries including South Africa. Nevertheless, this was not true in this survey as majority of the farmers that grew sweet potatoes tend to discard or burn the vines in the fields while a few use them for mulching to protect and enrich soil fertility. This was also confirmed by the least number of respondents who were willing to feed vines to livestock The possible reasons for discarding vines may depend on their perceptions and experiences. Salehi et al. (2014) explained that the discarding of crop residues instead of utilising them as feed is due to the insufficient knowledge and skill. Furthermore, sweet potato vines are not fed because farmers assume that it causes fatal diarrhoea to goats which may not be true if they are aware of the right proportion of supplementation.

\section{Conclusions}

The involvement of women and youth in agriculture is still a challenge since males are still dominating the industry. There is still a need to empower women in the agricultural industry. The majority of goat farmers seemed to know about or do some sort of supplementary feeding, but lack basic knowledge of the importance of indigenous forages. Moreover, the use of sweet potato vines as feed was rejected again due to lack of skills on how to properly feed supplements, especially highly nutritious feeds. There is therefore a need to develop farmers in goat farming through training and workshops concerning supplementary feeding of indigenous forages, for farmers to be able to supplement in a profitable manner and eradicate the myth of vines being fatal to goats. Farmers revealed that they still use indigenous knowledge of supplementary feed and cure the diseases of their animals. Indigenous knowledge and experiences should be considered since they are the most important tool that sustains smallholding farmers. Farmers that were using drugs as a cure for helminths seemed to be using one active ingredient over and over, which may lead to resistance; thus, more interventions are required to assist in developing animal health programmes. There is also a need to develop goat farming business skills of smallholding farmers, to ensure proper production, reproduction and animal health and feeding strategies. However, this may be achieved in a small-scale farmer environment through encouraging the use of highly nutritious crop residues such as sweet potato vines. Vines seem to be available to all farmers. Those that are not cultivating sweet potatoes may get them from farmers who had a surplus or neighbouring farmers not keeping goats but cultivating sweet potatoes, thus increasing the productivity and profitability of goats and the whole livestock enterprise. 


\section{Acknowledgements}

The authors extend their appreciation to the National Research Fund (NRF) who sponsored this study and would also like to thank the staff of KZNDepartment of Agriculture, and Rural Development in Umhlathuze local office and Owen Sithole College of Agriculture-Grassland Science Research and Farm Services.

\section{Authors' contributions}

CF, FF and BG conceptualised and designed the work. CF collected the data. $F F$ and $B G$ analysed the data. CF and BG visualised the results. CF and BG wrote the paper. BG and FF proofread the manuscript. All authors read and approved the final manuscript.

\section{Funding}

The authors are grateful to NRF for the financial support.

Availability of data and materials

Kindly contact the author for data requests.

\section{Ethics approval and consent to participate}

This study was approved by the Ethics Research Committee from the University of Zululand, South Africa, with ethical clearance number UZREC171110-030 PGM 2016/292. Interviewers were only conducted after consent forms had been signed indicating the willingness to participate freely.

\section{Consent for publication}

Not applicable.

\section{Competing interests}

The authors declare that they have no competing interests.

\section{Author details}

${ }^{1}$ Department of Agriculture, Faculty of Science and Agriculture, University of Zululand, Private Bag X 1001, Kwa-Dlangezwa 3886, South Africa.

${ }^{2}$ KwaZulu-Natal Department of Agriculture and Rural Development, Private Bag X 20013, Empangeni 3880, South Africa. ${ }^{3}$ Department of Agricultural Economics and Animal Production, Faculty of Science and Agriculture, University of Limpopo, Private Bag X1106, Sovenga 0727, South Africa.

Received: 5 March 2019 Accepted: 6 August 2019

\section{Published online: 19 November 2019}

\section{References}

Agyepong, A.O. 2009. The possible contribution of Moringa oleifera lam. leaves to dietary quality in two Bapedi communities in Mokopane, Limpopo Province. (Doctoral dissertation, Department of Human Ecology, University of South Africa).

Braker, M.J.E., H.M.J. Udo, and E.C. Webb. 2002. Impact of intervention objectives in goat production within subsistence farming system in South Africa. South African Journal of Animal Science 33 (3): 185-191.

Department of Agriculture, Forest and Fisheries, South Africa (DAFF) 2011. A profile of the South African sweet potato market value chain. (www.daff.gov.za).

Gwaze, F.R., M. Chimonyo, and K. Dzama. 2009. Communal goat production in Southern Africa: A review. Tropical Animal Health and Production 41 (7): 1157.

Gwaze, F.R., M. Chimonyo, and K. Dzama. 2010. Relationship between nutritionalrelated blood metabolites and gastro-intestinal parasites in Nguni goats of South Africa. Asian-Australasian Journal of Animal Science 9: 1190-1197.

Hadgu, G.Z., T. Negesse, and A. Nurfeta. 2014. Chemical composition and in vitro dry matter digestibility of vines and roots of four sweet potatoes (Ipomoea batatas) varieties grown in southern Ethiopia. Tropical and Subtropical Agroecosystems $17 \mathrm{http}: / /$ www.revista.ccba.uady.mx/ojs/index.php/TSA/ article/view/2018.

Hesterberg, U., R. Bagnall, K. Perrett, and B. Gummow. 2007. A questionnaire survey of perceptions and preventive measures related to animal health amongst cattle owners of rural communities in KwaZulu-Natal, South Africa. Journal of the South African Veterinary Association 78: 205-208.

Hodges, J., M. Foggin, R. Long, and G. Zhaxi. 2014. Globalisation and the sustainability of farmers, livestock- keepers, pastoralists and fragile habitats. Biodiversity 15: 109-118.

Kunene, N.W., F.N. Fon, and Z.C.S. Qwabe. 2015. Management of Nguni goats to control gastrointestinal parasites and anthelmintic resistance at
KwaMthethwa and Owen Sitole College of Agriculture area. African Journal of Agricultural Research 10: 1197-1202.

Maassa, B.L., W.L. Chiuri, R. Zozo, D. Katunga-Musale, T.K. Metre, and E. Birachi. 2013. Using the 'livestock ladder' as a means for poor crop-livestock farmers to exit poverty in Sud Kivu province, eastern DR Congo. In Agro-ecological intensification of agricultural systems in the African highlands, edited by Bernard Vanlauwe, Piet van Asten, Guy Blomme, 145-155. Abingdon: Routledge.

Mahanjana, A.M., and P.B. Cronje. 2000. Factors affecting goat production in the communal farming system in the Eastern Cape region of South Africa. South African Journal of Animal Science 30: 149-154.

Meira, M., E.P.D. Silva, J.M. David, and J.P. David. 2012. Review of the genus Ipomoea: Traditional uses, chemistry and biological activities. Revista Brasileira de Farmacognosia 22: 682-713.

Meissner, H., M. Scholtz, and A. Palmer. 2013. Sustainability of the South African livestock sector towards 2050 part 1: Worth and impact of the sector. South African Journal of Animal Science 43: 282-297.

Motsa, N.M., A.T. Modi, and T. Mabhaudi. 2015. Sweet potato as a drought tolerant and food security crop. South African Journal of Science 111: 1-8.

Munyai, F.R. 2012. An evaluation of socio-economic and biophysical aspects of small-scale livestock systems based on a case study from Limpopo Province: Muduluni Village (Doctoral dissertation, University of the Free State).

Naidoo, S.IM., S.M. Laurie, D.A. Odeny, B.J. Vorster, W.M. Mphela, M.M. Greyling, and B.G. Crampton. 2016. Genetic analysis of yield and flesh colour in sweetpotato. African Crop Science Journal 24: 61-73.

Rao, P.P. 2013. Importance of crop residues in the crop-livestock system in India and farmer's perceptions of fodder quality in coarse cereals. Field Crops Research 84: 189-198.

Reddy, V., S. Goga, F. Timol, and S. Molefi. 2016. The socioeconomics of livestock keeping in two South African communities: a black man's bank. Cape Town: HSRC Press.

Salehi, S., S. Lashikari, R.E. Abbassi, and H. Kamangar. 2014. Nutrient digestibility and chemical composition of potato (Solanum tuberosum L.) vine as alternative forage in ruminant diets. Agricultural Communications 2: 63-66.

SPSS, (2015). MOD, SPSS (statistic package of social science). Statistic South Africa, 2013. (www.statssa.gov.za).

Statistic South Africa, 2013. (www.statssa.gov.za).

Thornton, A. 2008. Beyond the metropolis: Small town case studies of urban and peri-urban agriculture in South Africa. Urban Forum 19: 243.

Tsheole, M.S., V. Malmbo, and M. Mwanza. 2016. A survey of production systems, management and marketing strategies for Tswana goats in semi-arid areas around Mafikeng, North West Province. Journal of Human Ecology 56 (1-2): 139-142.

\section{Publisher's Note}

Springer Nature remains neutral with regard to jurisdictional claims in published maps and institutional affiliations.

\section{Submit your manuscript to a SpringerOpen ${ }^{\circ}$ journal and benefit from:}

- Convenient online submission

- Rigorous peer review

- Open access: articles freely available online

- High visibility within the field

- Retaining the copyright to your article

Submit your next manuscript at $\boldsymbol{\nabla}$ springeropen.com 